Please do not remove this page

RMIT

UNIVERSITY

\title{
Supply chain management strategies of agricultural corporations: A resource dependency approach
}

O'Keeffe, Patrick

https://researchrepository.rmit.edu.au/esploro/outputs/9921860157201341/filesAndLinks?institution=61RMIT_INST\&index=null

O'Keeffe, P. (2016). Supply chain management strategies of agricultural corporations: A resource dependency approach. Competition and Change, 20(4), 255-274.

https://doi.org/10.1177/1024529416647146

Document Version: Accepted Manuscript

Published Version: https://doi.org/10.1177/1024529416647146

Repository homepage: https://researchrepository.rmit.edu.au

(c) The Author(s) 2016

Downloaded On 2023/04/27 01:13:36 +1000

Please do not remove this page 
Thank you for downloading this document from the RMIT Research Repository.

The RMIT Research Repository is an open access database showcasing the research outputs of RMIT University researchers.

RMIT Research Repository: http://researchbank.rmit.edu.au/

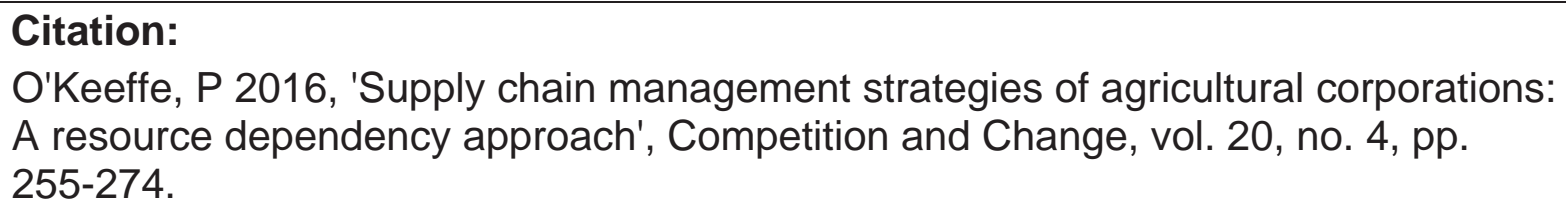

Version: Accepted Manuscript

Copyright Statement:

(C) The Author(s) 2016

Link to Published Version:

https://dx.doi.org/10.1177/1024529416647146 


\title{
Supply chain management strategies of agricultural corporations: A resource dependency approach
}

\author{
Patrick O’Keeffe \\ RMIT University, Australia
}

\begin{abstract}
:
The Australian federal government introduced the deregulation of the wheat export market in 2008 , as a means of creating a competitive wheat industry. However, this initiative did not sufficiently consider the potential for agricultural corporations to proactively seek to shape their environment. Utilising resource dependency theory, this article analyses the strategies employed by agricultural corporations, such as acquisitions, integration and geographic expansion, to develop control of supply chains and markets, and mitigate risks associated with resource supply and competition. Despite leading to a concentration of markets and consolidation within supply chains, agribusiness corporations manipulate discourse around food to promote these strategies as necessary to enhance global food security. Furthermore, this article analyses the use of political lobbying by agricultural corporations to create a regulatory environment which enables integration and expansion. This article enables resource dependency theory to be more directly observable, through analysing tangible examples of these associated practices, implemented by agricultural corporations. In addition, this article contends that through heightening awareness of how firms respond to deregulation, resource dependency theory provides the tools to reflect critically on the aims and methods of government deregulation initiatives.
\end{abstract}

Key Words: Resource dependency theory, supply chain management, agricultural corporations, deregulation, competition, wheat. 


\section{Introduction}

The global agribusiness firms known as the ABCD companies, Archer Daniels Midland (ADM), Bunge Limited (Bunge), Cargill and Louis Dreyfus Commodities (Louis Dreyfus), employ vertically integrated supply chain management strategies, with each of these firms employing tens of thousands of workers globally, across numerous geographically diverse regions (Murphy et al., 2012; Cargill, 2015a; ADM, 2016a; Louis Dreyfus, 2011; Bunge, 2016). The ABCD companies describe their activities as being focused on improving food security, which they contend, is achieved through their capacity to develop integrated supply chains, established through investment strategies including mergers, acquisitions and joint ventures (Louis Dreyfus, 2012; MacLennan, 2014, ADM, 2016b, Bunge, 2015a). While these strategies are often framed as necessary to mitigate risk, the result of this approach is consolidation within agricultural industries such as wheat (Clapp, 2015; Murphy et al., 2012; Ahmed, Hamrick and Gereffi, 2014; ADM, 2013). However, this is incongruent with government approaches to developing competitive industries and markets, through implementing programs of deregulation. This article explores strategies such as integration and consolidation, ostensibly implemented by the ABCD companies as a means of reducing risk, to understand how this may impact the objective of the Australian federal government to develop competition within the wheat export market.

In analysing perceptions of, and subsequent strategies designed to mitigate, risk and uncertainty by the $\mathrm{ABCD}$ companies, this article employs resource dependency theory as a lens through which to understand this activity. Developed by Pfeffer and Salancik (1978), resource dependency theory contends that firms will seek to develop their resources, through strategies such as mergers, acquisitions and joint ventures, to sustain competitive advantage on the one hand, and reduce uncertainty, on the other (Crook and Coombs, 2007; Bretherton 
and Chaston, 2005; Connelly et al., 2013). Although this theory is particularly well suited to analysing the use of integration by agribusiness, this framework has rarely been applied within an agricultural context. Furthermore, while studies have sought to explore changes in wheat prices following deregulation of the Australian wheat export market (Mugera et al., 2016; Williams, 2012), and the impacts of deregulation on wheat farmers (O'Keeffe, 2014; Head et al., 2011), the actions of companies within this recently deregulated market are yet to be explored.

To understand why these strategies of integration are employed by the ABCD companies, this article analyses annual reports, media releases, statements to investors, speeches and comments attributed to company spokespeople in news articles. In particular, statements from these sources relating to the ambitions of the company, merger and acquisition activity, risk and uncertainty, geographical diversification, or which contribute to discourse around trade and food security have been included in this analysis. Understanding the employment of organisational strategies by the ABCD companies, through analysing discourse, builds upon the work of Murphy et al. (2012) and Clapp (2015), who argue that these companies seek to shape discourse around food policy. Furthermore, this article focuses upon the ABCD companies due to their position as the dominant global agribusiness companies, controlling over 70 per cent of the global grain trade (Murphy et al., 2012; Clapp, 2015).

This article commences with an outline of resource dependency theory, focusing on how this theory enables and understanding of firm behaviour with regard to resources, relationships and risk, before exploring how this theory informs a comprehension of political action by firms. Following this, the deregulation of the Australian wheat industry is examined. This article then focuses on the strategies that are employed by the ABCD companies to develop resources, reduce risk and influence policy development. Following this, implications for the deregulated Australian wheat export market are considered. This article will argue that while 
strategies of integration and expansion are framed by the ABCD companies as risk-reducing, risk is managed through approaches which provide the company with control of grain networks and markets. As these strategies are dependent upon government regulations which allow companies to freely implement these strategies, the companies seek to mitigate the risks posed by policy shifts by exerting influence over policy development. This article contends that while governments may intend to create competition by deregulating agricultural industries, such policy may not achieve this objective without sufficient consideration of how firms may respond in deregulated environments.

\section{Dealing with uncertainty: a conceptual approach}

In positing a conceptual approach to analyse the behaviour of $A B C D$ firms three strands of thinking are drawn on; resource dependency theory, the issues of risk and uncertainty and firms as agents through corporate political action.

\section{Resource Dependency Theory}

Resource dependency theory provides an important framework for understanding the power of organisations, and how these organisations interact with their environment (Davis and Cobb, 2010; Wry, Cobb and Aldrich, 2013). This develops on Emerson's theory of powerdependent relations (1962), which contends that the more dependent firm 1 is on firm 2, the more power firm 2 has over firm 1. In addition, the work of Blau (1964), in analysing the instability of these relationships was particularly influential. According to resource dependency theory, the survival of firms is directly related to their capacity to reduce uncertainty of resource supply, particularly through reducing their dependencies on other firms (Bretherton and Chaston, 2005; Hessels and Terjessen, 2010; Cascario and Piskorksi, 2005; Drees and Huegens, 2013). Resources could be defined as physical, financial, political or informational (Wry et al., 2013). With regard to agribusiness, resources might include the 
raw commodity; physical assets such as grain elevators, ports or transport; financial resources necessary to make acquisitions; or the political resources that may assist the firm in influencing policy development. Studies employing resource dependency theory therefore seek to understand how firms use existing resources, what motivates firms to develop new resources, and how resource dependent relationships with other firms are managed (Bretherton and Chaston, 2005; Mottner and Smith, 2009; Paulraj and Chen, 2007; Hofer, 2012; Elg, 2000). In developing their resource base, resource dependency theory contends that firms will proactively seek to influence their environment (Drees and Huegens, 2013; Gulbrandsen et al., 2009). This underscores the differences in approach to other organisational theories such as population ecology, which contends that firms adapt to, rather than change, their environments (Nienhuser, 2008; Davis and Cobb, 2010). This relates to the mitigation of risks and uncertainties arising from the environment of the firm, which will now be explored.

\section{Risk and Uncertainty}

Resource dependency theory posits that firms will seek to reduce the uncertainties existing in their environment. Uncertainty is described by Pfeffer and Salancik (2003, p.67) as being the "degree to which future states of the world cannot be anticipated and accurately predicted". From within this framework, the external environment, that which is beyond the immediate and direct control of the firm, will be the greatest source of uncertainty for a firm (Nienhuser, 2008). The exposure of a firm to uncertainty and risk can be caused by relationships with other firms, competition from rival firms and the dependency of a firm on another for access to key resources (Mottner and Smith, 2009; Finkelstein, 1997; Carter and Rogers, 2008). Uncertainty may be caused by an unstable, or unfavourable, political environment (Hillman et al., 2009). These uncertainties may centre on access to necessary resources, the potential actions of competitors, government policies and regulations, and further environmental 
changes that were not anticipated by the firm (Nienhuser, 2008, Chen, Chen and $\mathrm{Ku}, 2012$; Malatesta and Smith, 2014). Studies which have sought to understand mergers and acquisitions implemented by firms have found that the prevalence of these strategies is increased when uncertainty is present in the operating environment (Nienhuser, 2008; Drees and Huegens, 2013; Pfeffer, 1972; Paulraj and Chen, 2007).

Less attention has been focused on the uncertainties resulting from competition, and the strategies that may be employed by firms to reduce exposure to these uncertainties (Sheppard, 1995). In addition, Pfeffer and Salancik (1978) contend that the uncertainties arising from competition can be mitigated through horizontal integration. In this sense, a firm may engage in mergers or acquisitions to reduce competition within a segment of a supply chain. This may result in the reduction in the number of competitors present within the market, and therefore increase the market share, and market power, of the firm. Associated with this, is the reduced risk that the firm may be subject to price competition. Furthermore, these strategies may be employed as a defensive strategy, aimed at reducing the potential for external firms to enter a market through acquisitions.

Uncertainty is a broadly defined term in resource dependency theory. However, if uncertainty is created by the external environment of the firm, and it is governments that regulate that environment, then in many ways uncertainties can be related to policy governing firm behaviour. For example, government policy could potentially limit the use of strategies such as vertical integration, or limit the growth of a firm within a market by restricting horizontal integration. Therefore it is now important to focus on the development of political resources by firms.

\section{Corporate Political Action}


Resource dependency theory enables an understanding of how the firm may seek to alter their environment to create a more favourable business climate (Wry, Cobb and Aldrich, 2013; Johnson, 1995; Nienhuser, 2008; Davis and Cobb, 2010; Getz, 1997; Bouwen, 2002). The environment can be considered to include external firms, though this also encapsulates the regulations and policies established by governments, which can restrict or protect the behaviours in which firms engage (Hillman et al., 2009). Hillman et al. (2009) contend that an important chapter from Pfeffer and Salanick's (2003) book External Control' is frequently overlooked; specifically the hapter "The Created Environment: Controlling Interdependence Through Law and Social Sanction"”. Wry et al., summarise the implications of this neglected chapter well (2013, p.449):

Pfeffer and Salancik's idea was straightforward: if firms are unable to reduce uncertainty and dependence, they will seek to create a new, more favourable environment by establishing, altering, or dismantling government regulations.

This is particularly relevant, the previous section has suggested, because competition and government regulation may be conceptualised by firms as a source of uncertainty. This can also lead to coalitions of firms developing, who may have shared ambitions with regard to how government policy is influenced (Henry, 2011). Henry (2011) states that these coalitions "are held together by power seeking relationships that better enable individual network actors to affect policy change" (:379). Henry (2011: 379) refers to the development of relationships between firms, termed "advocacy coalitions", which are based upon shared policy ideas, and the contention that these firms should seek to influence policy.

The development of political resources by firms as a means of creating a more favourable environment is a relatively undeveloped area of resource dependency theory. Studies exploring this aspect of firm behaviour have focused particularly on the use of board interlocks and political ties (Hillman, 2005; Mullery et al., 1995; Boyd, 1990; Haunschild, 
1993). Yet surprisingly little research has been conducted with regard to attempts of firms to influence policy through shaping discourse. Furthermore, studies have tended to focus on the development of political resources, while not connecting this with the identification of sources of uncertainty which may be mitigated through the deployment of these resources. This article will now turn to the Australian wheat industry, to explore how and why deregulation of the export wheat market came to be implemented, before conducting a preliminary analysis of the outcomes of deregulation.

\section{Context: the deregulation of the Australian wheat export market}

The deregulation of the Australian wheat export market effectively ended the export monopoly held by the Australian Wheat Board (AWB). This followed more than two decades of debate concerning the position of the AWB as a Statutory Marketing Authority, which had been established in 1948 with the intention of providing wheat growers with security and stability in their wheat marketing (Higgins and Lockie, 2002; Botterill, 2012; Whitwell and Sydenham, 1991). Throughout much of the 1980s, 1990s and 2000s, the Industries Assistance Commission (later known as the Productivity Commission) contended that deregulation was essential to expose the wheat industry to competition, which would theoretically lead to improvements in efficiency and productivity (Industries Assistance Commission, 1983; 1988; Irving, Arney and Linder, 2000; Productivity Commission, 2005). This perception ultimately informed wheat export market deregulation, implemented by the Australian federal government in 2008 (The Age, 2008).

However, following deregulation, the bulk handling companies such as GrainCorp (in the Eastern states of Victoria, New South Wales and Queensland), Glencore (South Australia) and $\mathrm{CBH}$ (Western Australia) control between 30 to 50 per cent of the export market in their respective states (Stretch, Carter and Kingwell, 2014; Australian Crop Forecasters, 2015). 
These bulk handling companies manage the infrastructure developed while these supply chains were under the regulated management and ownership of the state governments through the state-based bulk handling authorities (Stretch et al., 2014). To a significant extent, the control of the supply chains has been used by the bulk handling companies to extract a substantial share of the export market (Stretch et al., 2014; Boaitey, 2013).

The strong position of the vertically integrated bulk grain handlers within the Australian export market highlights the relationship between control of the supply chain as a means of developing a substantial share of a market. This article will now analyse the merger and acquisition strategies which have been employed by Archer Daniels Midland, Bunge Limited, Cargill and Louis Dreyfus, known as the ABCD companies, as a means of developing their control of supply chains within Australia, and subsequently, developing their share of the Australian wheat market.

\section{Management strategies of the ABCDs to reduce risk}

\section{Acquisition}

The larger transnational agribusiness companies have yet to develop supply chains to rival those of the bulk handling companies such as GrainCorp and CBH. Subsequently, the bulk handling companies have become targets for acquisition. For example, Archer Daniels Midland launched a A $\$ 3.4$ bn takeover of GrainCorp, which was rejected by the Australian government in 2013 (Hockey, 2013). However, the ousting of former Liberal Prime Minister Tony Abbott has led to speculation that ADM may make another bid for GrainCorp (Sydney Morning Herald, 2015).

While the ownership of GrainCorp remains a significant issue for the Australian wheat industry, numerous acquisitions of integrated companies have occurred in recent years. The most notable of these is Viterra's acquisition of ABB Grain in 2009, and was in turn 
purchased by Glencore in 2011 (Sydney Morning Herald, 2012). Viterra's control of the wheat supply chain in South Australia, in particular, enabled Glencore to increase their share of the Australian wheat export market from 6.7 per cent in 2010 to 22.0 per cent in 2013 (Australian Grain Growers Co-operative, 2014). This established Glencore as the second largest exporter of wheat from Australia (Australian Grain Growers Co-operative, 2014). Also in 2011, Cargill acquired AWB Grainflow, including their 22 grain receival sites in the Eastern states (Sydney Morning Herald, 2011). Louis Dreyfus acquired fertiliser company Ravensdown in 2014 (Farm Weekly, 2014), which followed their establishment of a joint venture with Asciano in 2011 to develop a grain handling facility in Newcastle (ABC, 2014). Bunge have thus far focused primarily on building their own infrastructure, including a A $\$ 20 \mathrm{~m}$ port in Geelong, Victoria, and A $\$ 40$ bn port in Bunbury, Western Australia; in addition to substantial storage facilities intended to supply these ports (The Australian, 2014, The Land, 2015).

Numerous acquisitions have been completed following the deregulation of the export wheat market in 2008, which raises the question of why these strategies are being employed, and also what the impact of these strategies has been. At this point, we must now turn to the broader strategic motivations of these companies, particularly with regard to the development of resources, and the management of risk and uncertainty as a means of understanding the implementation of acquisitions, mergers and joint ventures within the context of the Australian wheat industry.

\section{Vertical and horizontal integration}

As indicated by the merger and acquisition activity occurring within the Australian wheat industry, companies controlling wheat supply chains, or simply infrastructure supporting these supply chains, are particularly susceptible to acquisition from the major global 
agribusiness companies. The attempted acquisition of GrainCorp by ADM reflects a focus of this company upon investing in integrated firms. In addition to the existing 19.8 per cent interest of ADM in GrainCorp, this includes the 32.2 per cent interest of ADM in Pacificor, which owns grain elevators in Washington and Oregon; and a 100 per cent ownership of Alfred C. Toepfer International (ADM, 2015a, p.6). Louis Dreyfus have also targeted integrated firms in their acquisition strategies, having completed a takeover of Ilomar Holding N.V., (Louis Dreyfus, 2014), an acquisition which Jean-Marc Foucher, CEO of Louis Dreyfus Commodities for Europe and the Black Sea, claims "is consistent with the ambition of Louis Dreyfus Commodities to grow its fixed asset base and provide customers globally with integrated supply chain management solutions, from origin to final destination" (Louis Dreyfus, 2014). This integration and expansion is explained in the 2014 Louis Dreyfus Annual Report in relation to the "core expertise" of the company, which is outlined as "Securing supplies of food in a changing world" (Louis Dreyfus, 2015, p.3).

Bunge describe themselves as an "active acquirer of other companies" (Bunge, 2015b, p.12). This focus is part of Bunge's "Winning Global Footprint" plan, where the company seeks to "Invest in origination and distribution network to expand grain flows" (Bunge, 2014a). In addition, Executive Vice President of ADM, Ray Young, states that "Despite the macroeconomic headwinds that we're facing, we have an incredible portfolio of businesses and products and a geographic footprint that's really unparalleled” (ADM, 2016a, p.8). In each of these statements the development of resources in geographically diverse locations through acquisitions, is considered as essential in reducing risks associated with access to inputs, and also revenue volatility. Conversely, the "limited control over governance and operations" associated with the use of joint ventures is highlighted by Bunge (2015a, p.12), which results in "certain operating, financial and other risks relating to these investments". This implies that control within supply chains is perceived as being of significant importance, 
and is counter posed with risk. In that sense, risk is created when control is ceded. This is exemplified by a statement from Louis Dreyfus (2016):

We strive to strictly manage the journey from farm to fork... The greater the control we have, the greater the security and value we provide to our customers.

Control in this instance is mentioned with regard to security and value, concerning the capacity of the company to ensure quality of product is maintained. Joint ventures restrict this ability to control "the journey from farm to fork". This indicates that acquisition is the preferred strategy of agribusiness corporations, while also suggesting that these firms may engage in joint ventures with some reluctance. Yet as emphasised by ADM CEO Juan Luciano (ADM, 2015b, p.5), control of value chains maximises profitability:

...we can capture value as value sometimes shifts from one place in the value chain to the other. So this long view allows us to profit a lot from our system.

This reflects Bunge's emphasis on enhancing profitability through focusing on "value-added" activities, coupled with an intention to reduce revenue volatility (Bunge 2015c, p.23). The idea of control is also particularly interesting in this instance, and differs significantly from the approach of modern corporations described by Davis (2013), which eschew control of supply chains through direct ownership. Integral to this, is the notion of risk, and the relationship between risk and control within agribusiness.

\section{Geographical expansion}

This relationship between control and risk is particularly interesting with relation to the key strategies that are employed by global agribusiness companies. In particular, ambitions of agribusiness companies to expand their presence in global markets, and expand into geographic locations throughout the world, are of interest to this analysis. 
Rather than producing food, the ABCD companies describe the management of supply chains as their core business; however this is frequently constructed as serving a higher principle. As Serge Schoen, then CEO of Louis Dreyfus explains, "Our ambition is to feed and clothe people around the world by connecting farms to forks in every place where there is a need" (Louis Dreyfus, 2011, p.3). Cargill CEO David MacLennan (MacLennan, 2014) describes the activities of his company in a similar manner, stating "We move food and crops from times and places of surplus to time and places of deficit". According to Bunge (2015a, p.15), "As we deliver on our strategies, the benefits will accrue not only to our shareholders but to society as a whole. This is because what Bunge does is fundamental...connecting harvests to homes". ADM explain that their fundamental purpose is "To serve vital needs", also achieved by "connecting the harvest to the home" (ADM 2016c). The implication of these comments is that these firms are integral to global food networks, conveying a considerable level of power. This suggests that to disrupt the capacity of these companies to connect farms with consumers would be to disrupt global food security. In meeting these ambitions, Alberto Weisser, former Bunge CEO contends that agribusiness companies need to "be large and present in all different regions, well capitalised, have a complete portfolio" (cited in Ahmed, Hamrick and Gereffi, 2014, pp.12-13). Therefore, according to Weisser, consolidation of markets and also supply chains is essential. A comparable approach is demonstrated in ADM's 2014 10-K report (ADM, 2015a, p.12), who describe their strategy as "Expanding the volume and diversity of crops it merchandises and processes, expanding the global reach of its core model". This provides a sense that expansion, and also the capacity to expand, is critical to these firms.

Expansion of business into new countries and new regions, referred to as 'geographical diversification', is frequently cited by large agribusiness corporations as being fundamental to their global strategy (ADM, 2015a, 2015b; Louis Dreyfus, 2012; Bunge, 2014b). This is often 
portrayed as being important in securing consistent access to resources, thereby minimising revenue volatility (ADM, 2015b, p.4). From this perspective, developing a diversified global footprint is a means through which risk and uncertainty associated with resource supply can be mitigated. In the case of climatic events which may restrict the flow of resources from one region, a geographically diversified company is able to offset this reduction in resource supply through focusing on procuring resources from another region. Furthermore, as food production is seasonal, geographical expansion and diversification allows companies to ensure a consistent supply of resources, and consistent revenue streams, throughout the year. This geographical expansion is associated with the ambition to access new and developing markets (ADM, 2015c, p.4):

While geographical expansion is portrayed as essential in reducing the risks associated with resource supply and revenue volatility, the expanded reach of these companies places them in a position of significant power over global food networks. This power manifests through a presence in markets and locations across the world, which is frequently alluded to when companies provide a description of their activities and their global presence. For example, Juan Luciano of ADM states that:

So ADM, as of December 31, was about $\$ 33$ billion market cap[italisation]. It's certainly a global leader in origination of grain, processing of grain and ingredients. We have more than 750 facilities around the world (ADM, 2015b).

In that sense, geographic expansion, expressed through the number of facilities ADM controls, is used to portray the company as being powerful. Associated with this geographical expansion of ADM in this statement, is the enhanced profitability and value of the company. This omnipresence is described by Louis Dreyfus (2016) in the "A glass of orange juice poured for breakfast. A bowl of rice steamed for lunch. A cup of coffee served in a neighbourhood café. Throughout the day and throughout the world, Louis Dreyfus 
Commodities plays a vital role in nourishing the world's population". Such statements illustrate the importance of Louis Dreyfus and other ABCD companies in feeding populations, however also convey a pervasiveness which could be interpreted as an expression of power and control.

This research has highlighted the desire of agribusiness, specifically the ABCD companies, to develop their ownership of integrated supply chains, particularly through investments such as acquisitions. This analysis contends that such an approach serves the dual purpose of reducing the exposure of the company to risk, while allowing the company to develop control within food systems. In addition, this enables such companies to maximise the profit that can be extracted from these chains. In that sense, control is integral, and loss of control is equated with risk. These strategies are typically framed as integral to meeting key objectives such as connecting 'harvests to homes' or 'farms to forks', portraying the firms as being integral to food security. This reflects an attempt to shape discourse around food policy, with government regulations restricting these strategies framed as threatening global food security. Therefore, this article will now focus on the perceptions of agribusiness toward the risks posed by regulation and government policy.

\section{Managing regulation to reduce risk}

\section{Risks of regulation}

While the integration of supply chains may be employed to reduce risks associated with the supply of resources, and conversely, may assist agribusiness companies in developing control within food networks and subsequently capture value, the following analysis explores how risks to strategies of integration, consolidation and expansion - particularly government regulation and competition - are viewed by the companies. 
ADM highlight the inherent risks that may inhibit their operation with regard to a broad range of policy areas, "including anti-trust and competition law, trade restrictions, food safety regulations, and other government regulations and mandates" (ADM, 2015a, p.12). A similar statement is provided by Bunge (2015a, p.11), mentioning that "Governmental policies affecting the agricultural industry, such as taxes, tariffs, duties, subsidies, import and export restrictions...can influence industry profitability". While these statements draw the connection between the capacity of the company to expand into new markets and regions; regulation and policy restricting this expansion is viewed as being a considerable risk to the profitability of the company.

This article has cited geographic expansion, expansion into new markets and unrestricted trade as being fundamental to the strategies employed by global agribusiness companies. However as stated in the Bunge 10-K report for 2014 (Bunge, 2015b, p.11), "agricultural commodity production and trade flows are significantly affected by government policies and regulations". This indicates that regulation which may disrupt trade, and limit the capacities of companies to cross borders and enter new markets, represents a substantial risk to global agribusiness. Associated with this, is the discourse developed by the ABCD companies in particular, which articulates that free trade, movement of capital and the intervention of these global agribusiness companies into markets and regions throughout the world is of net benefit to societies. However, if these strategies are constructed as providing net benefits to societies within nations, then this may reduce the risk of regulation that restricts the capacity of global agribusiness companies to execute these strategies which appear fundamental to their profitability.

\section{Promoting market based approaches}


The perception of the ABCD companies of regulation as a risk, suggests their preference towards market based approaches to economic organisation. This is further emphasised by the consistent advocacy of the ABCD companies for unrestricted trade, and their endorsement of the power inherent within markets (Page 2014; MacLennan, 2014; Conway, 2013; Murphy et al., 2012). However, the vertically integrated approaches of ADM and Bunge, for example, indicate that the companies structures their activities to avoid participating in open markets, and avoid engaging in relationships with competing firms.

While deregulation may be implemented by governments as a means to create competition within agricultural markets, for agribusiness companies, competition is perceived as a risk to their operation. As stated by ADM (2015a, p.11), “Competition impacts the Company's ability to generate and increase its gross profit". While mergers, acquisitions and joint ventures are portrayed by firms as a means through which access to resources can be secured, and associated uncertainties can be reduced, such activity from competing companies can be perceived as a threat to their own viability. As stated by ADM (2015a, p.11):

...continued merger and acquisition activities resulting in further consolidations result in greater cost competitiveness and global scale of certain players in the industry that could impact the relative competitiveness of the Company.

This statement suggests that in some ways, mergers and acquisitions are engaged as defensive manoeuvres, aimed at reducing the capacity of competitors to strengthen their position in global markets and appropriate market share. The following statement illustrates this relationship between the capacity to compete, and the establishment of market share:

To compete effectively, the Company focuses on...developing and maintaining appropriate market share (ADM, 2015a, p.11). 
A similar concern regarding the risks associated with competition, the potential loss of market share, as well as increased costs and reduced revenue are articulated by ADM and Bunge in these statements:

Competition could cause us to lose market share...increase marketing or other expenditures or reduce pricing, each of which could have an adverse effect on our business and profitability (Bunge, 2015b, pp.12-13).

In this sense, competition is portrayed by $\mathrm{ADM}$ and Bunge as being a risk to their financial performance. Furthermore, profitability is connected to market share, suggesting that from the perspective of the company, the protection and expansion of their market share is essential. These statements suggest that competition is not viewed favourably by agribusiness corporations, which indicates that these companies may be inclined to explore means through which exposure to competition may be reduced. This relates to the use of integrated value chains as a means of reducing exposure of companies to open markets, and to reduce the competitiveness of a market.

Considering the operating environment of the company and the emphasis of companies on reducing the risks associated with competition, this raises the risks that may be associated with competition or antitrust policy. In particular, government policies regulating competitiveness of markets are also perceived by Bunge as being a risk to their profitability, which may be motivated by increasing commodity prices. As mentioned by Bunge (2015a, p.6):

High commodity prices and regional crop shortfalls have led, and in the future may lead, governments to impose price controls, tariffs, export restrictions and other measures designed to assure adequate domestic supplies and/or mitigate price increases in their domestic markets, as well as increase the scrutiny of competitive conditions in their markets. 
While governments may seek to open markets and encourage investment from agribusiness companies, the companies included in this research view competition and government policy designed to enhance competition within markets as significant risks to their profitability. This indicates that there is a disjuncture between the ambition of governments to develop competition in markets and the organisational strategies that are adopted by global agribusiness companies. The conceptualisation of competition as a risk implies that strategies utilised by these companies to reduce risk, will involve approaches which seek to reduce competition. In practice, the employment of strategies to reduce risk associated with competition, and avoid markets through vertically integrated structures, is at odds with the rhetoric from companies such as Cargill, Bunge, ADM and Louis Dreyfus, who actively promote free trade and free markets.

\section{Corporate Political Action}

The preceding sections have highlighted the perceived need of agribusiness to continually expand, in terms of geographic reach and also to develop control within value chains. This expansion is often facilitated by acquisitions, and in particular, acquisitions of integrated companies. However, as this article has shown, agribusiness corporations view government regulation which impacts trade, markets and the competitiveness of markets as potentially undermining these strategies. This article will now explore the use of political action by agribusiness as a means of reducing the potential impact of these risks.

An example of an attempt to shape policy discourse is reflected in the comments of ADM, contained within a submission to the Submission to the Senate Rural and Regional Affairs and Transport References Committee, essentially convened in response to the attempted takeover of GrainCorp by ADM (2013, p.6): 
There is a clear worldwide trend towards consolidation in agribusiness, where economies of scale and global market reach are increasingly essential in maintaining competitiveness (ADM, 2013, p.6).

This statement illustrates the contention of global agribusiness that competitive advantage is achieved through continual development and accumulation of resources. While the risks associated with competition are indicated through this statement, in addition, the risks that are posed by regulation seeking to maintain competitiveness in markets are apparent. Through presenting consolidation of agricultural markets as inevitable, this comment seeks to normalise consolidated markets. Furthermore, this seeks to connect the performance of ADM, achieved through economies of scale, with broader outcomes related to improved performance in food networks. In that sense, this statement aims to influence the Australian federal government's decision to either allow or prevent ADM's acquisition of GrainCorp. In this instance, ADM's attempt at exerting influence was in response to the environmental circumstances; however intervention of global agribusiness in policy discourse is often proactive. Potentially, this reflects the concern about "future government policies" (ADM, 2015a, p.12), which may impact strategies of geographic expansion and consolidation. To minimise these risks and protect their power and also profitability, agribusiness companies such as the ABCD's may seek to influence their environment through corporate political activity. As explained by former CEO of Cargill, Greg Page, who contended that "It is not for us to take on the roles of governments, although we should seek to inform their deliberations" (Page, 2014). According to Cargill Vice Chairman Paul Conway, "we advocate for policies and practices to help ensure that the world can feed itself' (Conway, 2013). The focus of the latter half of this sentence returns to the power held by the ABCD companies with regard to global food security. This is not only a significant expression of power, however this comment suggests that firms such as Cargill are best positioned to determine how food 
security can be achieved. Page (2015) elaborates on the position of Cargill in this regard, stating that food security can be reached through enabling "open trade", which therefore requires the discouragement of "political leaders worldwide from pursuing food selfsufficiency, imposing export barriers and taking other actions that inhibit food from moving freely across borders". Similarly, CEO of Cargill, David MacLennan (2015), and Conway (2012) contend free trade is required to mitigate the risks to food security that may be caused by climate change, or government intervention in markets. Conway (2012) summarises his speech by stating that in depicting the importance of free trade, he has outlined the "environments that governments can provide to help give the right incentives to farmers". The implication is that governments seeking to intervene in the activities of Cargill may risk the food security of their nation. Yet to some extent this also illustrates Cargill's vulnerability to government regulation, and highlights their perceived need to maintain some level of influence over government policy.

For example, if ADM (2014) or Bunge (2014b) consider that government regulations across areas such as competition policy and environmental regulation pose a risk to their strategy of expansion within markets and across borders, then these firms will seek to influence the development - or withdrawal - of these regulations. This can also lead to coalitions of firms developing, who may have shared ambitions with regard to how government policy is influenced (Henry, 2011). Examples of this activity in agribusiness include lobby group Food and Drink Europe, which represents member companies such as Cargill, Kellogg, Unilever and Coca-Cola (Food and Drink Europe, 2015). In addition, Cargill has been particularly active in lobbying for the endorsement of the Trans-Pacific Partnership (TPP) trade agreement, as "a founding member of the U.S. Business coalition for the TPP" (Cargill, 2015b). As stated by Cargill Vice President of Corporate Affairs Devry Boughner Vorwerk, the "TPP will allow food to move more freely across international borders, which is crucial to 
feed a growing world population" (Cargill, 2015b). According to MacLennan, (Cargill, 2015c) this freedom will "[benefit] farmers and consumers around the world". Similarly, ADM CEO Juan Luciano contends, “The TPP will help reduce barriers to trade and open new markets, benefiting American farmers and ranchers, the U.S. economy and ADM", while subsequently "supporting more American jobs and strengthening our rural communities" (ADM, 2015d).

With the profitability of operations of global agribusiness cited in this article as being dependent upon freedom of trade and capital flows, it is clear the TPP offers significant benefits for companies such as Cargill and ADM. However, it is important to note that these freedoms, provided by such an agreement, are portrayed by Vorwerk as being essential to "feeding a growing world population", or providing increased opportunities and employment for farmers. In that sense, policy which benefits Cargill and ADM, is constructed as ultimately benefitting the global community (Cargill, 2015c; ADM, 2015d). Crucially, in this argument it is not the power that can be amassed by these companies through the creation of such a trade environment, it is the benefits which are argued to be achieved by farmers and consumers, which are constructed as being relatively powerless. According to this argument, Cargill and ADM are able to empower these producers and consumers, while enhancing food security (Cargill 2012).

These attempts to intervene in policy and discourse around policy development are indicative of the tension between risk and control. Competition, and policy which may seek to enhance competitiveness of industry, is viewed as being a significant risk to the capacity of agribusiness to implement strategies such as integration and expansion. As with the perceived need to control risks associated with access to resources, quality of product and profit capture in value chains, intervention in policy is applied to seek some level of control over governmental decisions, and discourses informing those decisions. 


\section{Discussion}

The Australian wheat industry, which was deregulated in 2008, provides an interesting environment to examine through the lens of resource dependency theory. The deregulation of the industry ensured that Australian and transnational grain traders were able to enter the market. However bulk handling companies such as GrainCorp in Australia's Eastern states control the supply chains that were once owned by state authorities, which held monopolies over these networks until privatisation in the 1990s and early 2000s. In developing ownership of integrated supply chains, companies such as GrainCorp, Viterra and $\mathrm{CBH}$ have become acquisition targets, particularly from global agribusiness companies such as ADM, Bunge, Cargill and Louis Dreyfus, who are intent on developing integrated supply chains. Associated with this emphasis on integration, is the focus of these companies upon expanding their reach into new markets and new geographic regions.

This discussion therefore turns to understanding the strategies employed by these companies; specifically, exploring why these strategies are favoured, and the implications of this. In analysing documentation produced by the ABCD companies, such as media releases, speeches, annual reports, this research has highlighted risk as a key factor in the intention of these firms to develop integrated supply chains. This strategy ensures resource supply and minimises dependencies upon other companies - who may be competitors - within the supply chain. In addition, this enables the companies to reduce their exposure to revenue volatility. Associated with the minimisation of risk is the use of integration as a means to establish control of supply chains. From this perspective, the loss of control is perceived by the companies as creating risk. This is reflected in the use of integration to as a means of avoiding exposure to markets. In that sense, the need for control is motivated by the perceived correlation between control of supply chains and profit capture. 
These strategies are designed to maintain the global stability of the company, in terms of access to commodity, and consistency of revenue. In turn, this is also associated with the ambitions of the $\mathrm{ABCD}$ companies to expand in size and scope, through the approach of 'geographical diversification'. However, this strategy is dependent upon the approach of governments towards regulation of trade and markets. Therefore, government regulation and policy (and future policies which may restrict this activity) is framed by the ABCD companies as representing a significant risk. The contention of this article is that companies aiming to minimise risk in their environment will seek to influence government policy.

Firstly, the ABCD companies seek to shape discourse around trade and food security, in constructing their activities as ultimately delivering societal benefits. The companies portray themselves as being best placed to deliver food security on a global scale, which can be achieved if they are afforded the freedom to implement strategies of integration and expansion. Conversely, the companies outline their existing power within global food networks; routinely expressed in terms of global reach, size, employee numbers and market capitalisation. This effectively communicates the power of these companies to governments who may seek to regulate their activities, raise barriers to commodity and food trade, or develop a degree of self-sufficiency within national food networks. Also communicated are the financial and political resources that the companies may be able to implement to develop influence. As this research has highlighted, this is evident in the formation of business coalitions, including the U.S. Business Coalition for the TPP, Food and Drink Europe, and the Australian Grain Exporters Association.

Further to the potential risks associated with the regulation of trade, is the regulation of competition within markets. In deregulating the Australian wheat industry, the Australian federal government claimed that this was necessary to ensure greater competition, and resultantly, improved wheat prices for wheat farmers. However, regulation of competition 
within markets, and within supply chains, is perceived by the ABCD companies as potentially restricting their capacity to consolidate and expand the scope of their activities. In that regard, efforts by government to restrict the consolidation of markets are portrayed as not only lacking cognisance of the preference of 'the market' for large, well-capitalised companies; but are ultimately futile, in the face of the global shift towards market consolidation. Coupled with the risks that are posed by the regulation of competition, is the perception of risk created by competitors. This in turn leads to the employment of investment strategies such as acquisitions to protect market share. While companies such as Cargill or ADM advocate for the liberalisation of trade and the power of markets, in practice, the control of supply chains effectively shields the companies from markets and restricts competition.

The deregulation of the Australian wheat export market was intended to create competition. However, this paper contends that such an ambition does not correspond with the strategies of integration employed by global agribusiness. While integration is employed to reduce risk, this approach to risk management is focused on the establishment of control within supply chains. In addition, the targeting of investments such as acquisitions towards integrated companies leads to further consolidation. As a result of not considering these significant factors in the deregulation of the Australian wheat industry, the Australian government was therefore not able to substantially account for the power that could be developed by agribusinesses corporations within the deregulated environment. Accordingly, the unintended consequences of deregulation, such as a consolidation of the wheat export market, which may have been predictable, were not adequately considered.

\section{Conclusion}


This article has explored resource dependency theory as a framework for understanding the strategies of agricultural corporations in a deregulated market. Through analysing annual reports, media releases, statements to investors and SEC filings of the ABCD companies, this article has explored how these companies perceive risk and implement strategies such as acquisitions as a means of reducing risks associated with access to resources, revenue volatility and the actions of competitors. Expansion into new regions, framed as geographic diversification, is a key strategy designed to reduce these risks, and is employed in conjunction with an intention to develop integrated supply chains, often through acquisitions. Such strategies which reduce risk invariably involve the development of control. In that sense, the loss of control is framed as inherently creating risk. This article contends that the ABCD companies seek to shape discourse around food to justify these strategies through the contention that global food security is enhanced as a result. Associated with this, are attempts to lobby governments to reduce restrictions of trade and scrutiny of markets; actions which are framed by the ABCD companies as harmful to food security, farmers and consumers. Through exploring the tangible implications of strategies which seek to reduce risk, develop market share and expand geographically, this article makes a substantial contribution to resource dependency theory literature.

Utilising resource dependency theory to explore the power of firms in this context, the tension between firms reliant upon unencumbered transnational trade, and the sovereignty of individual nations, offers considerable potential. However, in studying the practices of the ABCD companies, such as the use of acquisitions, the shaping of discourse around food and food security, and intervention in policy, this paper makes resource dependency theory more relatable to the tangible implementation of corporate strategy, and therefore, more observable. 
Application of resource dependency theory is eminently relevant to the Australian wheat export market, which was deregulated by the federal government in 2008 to create a competitive industry. However, this policy shift was implemented without due consideration for the power of firms, or the capacity of firms such as the ABCD companies to proactively implement strategies with the intention of creating a favourable environment.

\section{Acknowledgements}

This research received no specific grant from any funding agency in the public, commercial, or not-for-profit sectors.

The author would like to thank two anonymous reviewers, Professor Jane Hardy and Dr

Nicole Pepperell for their helpful feedback and comments.

\section{References}

The Age, (2008), Split over wheat desk reform, [online] http://www.theage.com.au/news/business/split-over-wheat-deskreform/2008/03/13/1205126110679.html [Accessed December 16, 2015].

Ahmed, G., Hamrick, D., and Gereffi, G., (2014), Shifting governance structures in the wheat value chain: Implications for food security in the Middle East and North Africa, [online] http://europa.uniroma3.it/centrorossidoria/docs/public/Ahmed_Hamrick_Gereffi_150914.pdf [Accessed April 30, 2015].

ADM, (2016a), Archer Daniels Midland Co at Consumer Analyst Group of New York Conference, February 16 2016, [online] http://www.adm.com/ENUS/NEWS/PRESENTATIONS/Pages/default.aspx [Accessed February 29 2016].

ADM, (2016b), Connecting the harvest to the home, [online] http://www.adm.com/enUS/products/Documents/ADM-FPS-Brochure.pdf [Accessed March 17 2016].

ADM, (2016c), The ADM Way, [online] http://www.adm.com/enUS/company/ADM_way/Pages/default.aspx [Accessed March 15 2016].

ADM, (2015a), Form 10-K; Annual report pursuant to section 13 or 15(d) of the Securities Exchange Act of 1934, for the fiscal year ended December 31, 2013, [online] 
http://www.sec.gov/Archives/edgar/data/7084/000000708414000011/adm-

20131231x10k.htm [Accessed December 16, 2015]

ADM, (2015b), Archer Daniels Midland Co at Consumer Analyst Group of New York

Conference, February 17 2015, [online] http://www.adm.com/EN-

US/NEWS/PRESENTATIONS/Pages/default.aspx [Accessed March 1 2016].

ADM, (2015c), 2014 Annual Report, [online] http://www.adm.com/en-

US/investors/Documents/2014-ADM-Annual-Report.pdf [Accessed March 1 2016].

ADM, (2015d), ADM urges approval of Trans-Pacific Partnership, [online]

http://www.adm.com/news/_layouts/PressReleaseDetail.aspx?ID=691 [Accessed December $212015]$.

ADM, (2014), Form 10-K; Annual report pursuant to section 13 or 15(d) of the Securities Exchange Act of 1934, for the fiscal year ended December 31, 2013, [online] http://www.sec.gov/Archives/edgar/data/7084/000000708414000011/adm20131231x10k.htm [Accessed December 16, 2015].

ADM, (2013), Submission to the Senate Rural and Regional Affairs and Transport References Committee: The Ownership Arrangements for Grain Handling, [online] http://www.aph.gov.au/DocumentStore.ashx?id=ca1c7a14-741b-4d6c-a4e6d051dd054d84\&subId=5640. [Accessed December 16, 2015].

The Australian, (2014), Bunge to build grain export terminal at Geelong, [online] http://www.theaustralian.com.au/business/bunge-to-build-grain-export-terminal-atgeelong/story-e6frg8zx-1227031222192 [Accessed March 2 2016].

Australian Crop Forecasters, (2015), Shipping stem and market share report, [online] http://www.cropforecasters.com.au/ [Accessed December 21, 2015].

Australian Grain Growers Co-operative, (2014), Agricultural Competitiveness White Paper submission,

http://agwhitepaper.agriculture.gov.au/IP\%20Submissions\%20for\%20publication/201404\%20April/IP564\%20Australian\%20Grain\%20Growers.pdf [Accessed March 29 2016].

Blau, P., (1964), Exchange and power in social life, J.Wiley, New York.

Boaitey, A., (2013), Grain market deregulation: a case study of the Canadian and Australian wheat boards, Journal of Public Affairs, 13(3), pp.282-287.

Boyd, B., (1990), Corporate linkages and organisational environment: A test of the resource dependence model, Strategic Management Journal, 11, pp.419-430.

Botterill, L., (2012), Wheat marketing in transition, Springer, New York.

Bouwen, P., (2002), Corporate lobbying in the European Union: the logic of access, Journal of European Policy, 9(3), pp.365-390.

Bretherton, P., and Chaston, I., (2005), Resource dependency and SME strategy: an empirical study, Journal of Small Business and Enterprise Development, 12(2), pp. 274-289. 
Bunge Limited, (2016), Company: About Bunge, [online] http://www.bunge.com/AboutBunge [Accessed March 17 2016].

Bunge Limited, (2015a), Unlocking Value: 2014 Annual Report, [online] http://phx.corporate-ir.net/phoenix.zhtml?c=130024\&p=irol-reportsannual [Accessed March 7 2016].

Bunge Limited, (2015b), Form 10-K; Annual report pursuant to section 13 or 15(d) of the Securities Exchange Act of 1934, for the fiscal year ended December 31, 2014, [online] http://phx.corporate-ir.net/phoenix.zhtml?c=130024\&p=irol-sec [Accessed March 7 2016].

Bunge Limited, (2015c), Consumer Analyst Group of New York (CAGNY) Conference Presentation, [online] http://phx.corporate-ir.net/phoenix.zhtml?c=130024\&p=irolpresentations [Accessed March 7 2016].

Bunge Limited, (2014a), Investor Day: Agribusiness and risk management overview, October 12 2014, [online] http://phx.corporate-ir.net/phoenix.zhtml?c=130024\&p=irol-presentations [Accessed March 7 2016].

Bunge Limited, (2014b), Form 10-K; Annual report pursuant to section 13 or 15(d) of the Securities Exchange Act of 1934, for the fiscal year ended December 31, 2013, [online] http://www.sec.gov/Archives/edgar/data/1144519/000104746914001600/a2218521z10-k.htm [Accessed December 16, 2015].

Cargill, (2015a), Cargill to modernize, centralize its North American cocoa and chocolate business, [online] http://www.cargill.com/news/releases/2015/NA31904677.jsp [Accessed December 17, 2015].

Cargill, (2015b), Cargill supports continued progress in Trans Pacific Partnership negotiations, [online] http://www.cargill.com/news/company-statements/cargill-supportscontinued-progress-on-trans-pacific-partnership-negotiations/index.jsp [Accessed March 7 2016].

Cargill, (2015c), Trans Pacific Partnership trade agreement has potential to create more prosperous, food-secure world, [online] http://www.cargill.com/news/releases/2015/NA31897661.jsp [Accessed February 29 2016].

Cargill, (2012), Cargill welcomes the entry of Mexico and Canada into the Trans Pacific Partnership trade negotiations, [online] http://www.cargill.com/news/companystatements/mexico-canada-tpp-trade-negotiation/index.jsp [Accessed March 7 2016].

Carter, C., and Rogers, D., (2008), A framework of sustainable supply chain management: Moving toward a new theory. International Journal of Physical Distribution and Logistics Management, 38(5), pp.360-387.

Cascario, T., and Piskorski, M., (2005), Power imbalance, mutual dependence, and constraint absorption: A closer look at resource dependency theory, Administrative Science Quarterly, 50, pp.167-197. 
Chen, T., Chen, H., and Ku, Y., (2012), Resource dependency and parent-subsidiary capability transfers. Journal of World Business, 47, pp.259-266.

Clapp, J., (2015), ABCD and beyond: From grain merchants to agricultural value chain managers, Canadian Food Studies/La Revue canadienne des études sur l'alimentation, 2(2), pp.126-135.

Connelly, B., Ketchen, D., and Hult, T., (2013), Global supply chain management: Toward a theoretically driven research agenda, Global Strategy Journal, 3, pp.227-243.

Conway, P., (2013), Food security: The challenge ahead, Speech presented at the MIT Food Symposium - Cambridge, Massachusetts, November 52013 [online]

http://www.cargill.com/news/speeches-presentations/food-security-the-challengeahead/index.jsp [December 16 2015].

Conway, P., (2012), One billion farmers can't be wrong: Why prices and markets matter, February 8 2012, [online] http://www.cargill.com/news/speeches-presentations/one-billionfarmers-prices-markets-matter/index.jsp [Accessed March 29 2016].

Crook, T., and Combs, J., (2007), Sources and consequences of bargaining power in supply chains, Journal of Operations Management, 25, pp.546-555.

Davis, G., (2013), After the corporation, Politics and Society, 41(2), pp.283-308.

Davis, G., and Cobb, A., (2010), Resource dependence theory: Past and future, Research in Sociology of Organisations, 28, pp.21-42.

Drees, J., and Heugens, P., (2013), Synthesising and extending resource dependency theory: A meta-analysis, Journal of Management, 39(6), pp.1666-1698.

Elg, U., (2000), Firm's home-market relationships: Their role when selecting international alliance partners, Journal of International Business Studies, 31(1), pp.169-177.

Emerson, R., (1962), Power-dependence relations, American Sociological Review, 27, pp.3241.

Farm Weekly, (2014), Macrofertil to maintain Ravensdown network, [online] http://www.farmweekly.com.au/news/agriculture/cropping/general-news/macrofertil-tomaintain-ravensdown-network/2684587.aspx?storypage=0 [Accessed March 2 2016].

Finkelstein, S., (1997), Interindustry merger patterns and resource dependence: A replication and extension of Pfeffer (1972), Strategic Management Journal, 18, pp.787-810.

Food and Drink Europe, (2015), Members, [online] http://www.fooddrinkeurope.eu/aboutus/members/\#tab3 [Accessed December 16, 2015].

Getz, K., (1997), Research in corporate political action, Business and Society, 36(1), pp.3272. 
Gulbrandsen, B., Sandvik, K., and Haugland, S., (2009), Antecedants of vertical integration: Transaction cost economics and resource-based explanations, Journal of Purchasing and Supply Management, 15, pp.89-102.

Haunschild, P., (1993), Interorganisational imitation: The impact of interlocks on corporate acquisition activity, Administrative Science Quarterly, 38(4), pp.564-592.

Head, L., Atchison, J., Gates, A., and Muir, P., (2011), A fine-grained study of the experience of drought, risk and climate change among Australian wheat farming households, Annals of the Association of American Geographers, 101(5), pp.1089-1108.

Henry, A., (2011), Ideology, power, and the structure of networks. The Policy Studies Journal, 39(3), pp.361-383.

Hessels, J., and Terjesen, S., (2010), Resource dependency and institutional theory perspectives on direct and indirect export choices, Small Business Economics, 34, pp.203220.

Higgins, V., and Lockie, S., (2002), Re-discovering the social: neo-liberalism and hybrid practices of governing in rural natural resource management, Journal of Rural Studies, 18, pp.419-428.

Hillman, A., (2005), Politicians on the board of directors: Do connections affect the bottom line? Journal of Management, 31(3), pp.464-81.

Hillman, A., Withers, M., and Collins, B., (2009), Resource dependency theory: A review. Journal of Management, 35, pp.1404-1427.

Hockey, J., (2013), Foreign investment application: Archer Daniels Midland Company's proposed acquisition of GrainCorp Limited, [online]

http://jbh.ministers.treasury.gov.au/media-release/026-2013/ [Accessed December 16, 2015].

Hofer, C., Jin, H., Swanson, D., Waller, M., and Williams, B., (2012), The impact of key retail accounts on supplier performance: A collaborative perspective of resource dependency theory, Journal of Retailling, 88, pp.412-420.

Industry Assistance Commission, (1988), The Wheat Industry, Report No. 411, AGPS, Canberra.

Industry Assistance Commission, (1983), The Wheat Industry, Report No. 329, AGPS, Canberra.

Irving, M., Arney, J., and Linder, B., (2000), National Competition Policy review of the Wheat Marketing Act 1989, National Competition Policy - Wheat Marketing Act Review Committee, Canberra. 
Johnson, B., (1995), Resource dependency theory: A political economy model of organisations, [online] http://files.eric.ed.gov/fulltext/ED387871.pdf [Accessed April 30, 2015].

The Land, (2015), Bunge builds for a bigger grain share, [online] http://www.theland.com.au/news/agriculture/cropping/grains/bunge-builds-for-a-biggergrain-share/2722093.aspx?storypage=0 [Accessed March 15 2016].

Louis Dreyfus Commodities, (2016), What we do, [online] http://www.ldcom.com/global/en/about-us/what-we-do/ [Accessed March 8 2016].

Louis Dreyfus Commodities, (2015), 2014 Annual Report: Taking up challenges, [online] http://www.ldcom.com/global/en/investors-media/reports-and-publications/annual-report2014-interactive-pdf/ [Accessed March 15 2016].

Louis Dreyfus Commodities, (2014), Louis Dreyfus Commodities announce acquisition of Ilomar Holding N.V., [online] https://www.ldcom.com/global/en/investors-media/pressreleases/2014/louis-dreyfus-commodities-announces-acquisition-ilomar-holdi/ [Accessed March 15 2016].

Louis Dreyfus Commodities, (2013), 2012 Annual Report, [online] http://www.ldcom.com/global/en/investors-media/reports-and-publications/2013 [Accessed February 29 2016].

Louis Dreyfus Commodities, (2012), 2011 Annual Report, [online] http://www.ldcommodities.com.br/Sobre_LDC/documentos/20120423_Annual\%20Report_E nglish\%20Version.pdf [Accessed March 15 2016].

Malatesta, D., and Smith, C., (2014), Lessons from resource dependence theory for contemporary public and non-profit management, Public Administration Review, 74(1), pp.14-25.

Maclennan, D., (2015), Sustainability is the new normal, April 21 2015, [online] http://www.cargill.com/news/sustainability-is-the-new-normal/index.jsp [Accessed March 29 2016].

MacLennan, D., (2014), Hope for our planet: How a resilient global food system can feed a growing world, Rabobank Duisenberg Lecture, Presented on October 11, 2014, [online] http://www.cargill.com/news/speeches-presentations/hope-for-our-planet/index.jsp [Accessed December 16, 2015].

Mottner, S., and Smith, S., (2009), Wal-mart: Supplier performance and market power, Journal of Business Research, 62, pp.535-541.

Mugera, A., Curwen, R. and White, B., (2016), Deregulation of the Australian Wheat Export Market: What Happened to Wheat Prices?. Journal of International Food \& Agribusiness Marketing, pp.1-17. 
Mullery, C., Brenner, S., and Perrin, N., (1995), A structural analysis of corporate political activity: An application of MDS to the study of intercorporate relations, Business and Society, 34(2), pp.147-170.

Murphy, S., Burch, D., and Clapp, J., (2012), Cereal Secrets: The world's largest grain traders and global agriculture, [online] http://www.oxfam.org/sites/www.oxfam.org/files/rrcereal-secrets-grain-traders-agriculture-30082012-en.pdf [Accessed October 28, 2014].

Nienhuser, W., (2008), Resource Dependency Theory - How well does it explain behaviour of organisations? Management Review, 19(1+2), pp.9-32.

O'Keeffe, P., (2014), The impact of wheat export marketing deregulation upon wheat growers in Victoria's western Wimmera, Paper presented at the 57th Annual Conference of the Australian Agricultural and Resource Economics Society, February 4th-7th 2015, Port Macquarie.

Page, G., (2015), Climate change and the future of food production, October 122015 , [online] http://www.cargill.com/news/speeches-presentations/climate-change-and-the-futureof-food-production/index.jsp [Accessed March 29 2016].

Page, G., (2014), The price of responsibility, Presented at the FT Commodities Summit, Switzerland, [online] http://www.cargill.com/news/speeches-presentations/the-price-ofresponsibility/index.jsp [Accessed December 16 2015].

Paulraj, A., and Chen, I., (2007), Environmental uncertainty and strategic supply management: A resource dependence perspective and performance implications. Journal of Supply Chain Management, Summer 2007, pp.29-42.

Pfeffer, J., (1972), Merger as a response to organizational interdependence, Administrative Science Quarterly, 17(3), pp.382-94.

Pfeffer, J., and Salancik, G., (2003), The external control of organisations: A resource dependence perspective, Stanford University Press, California.

Pfeffer, J. and Salancik, G., (1978), The External Control of Organizations: A Resource Dependence Perspective, Harper and Row, New York.

Productivity Commission, (2005), Review of National Competition Policy reforms: Productivity Commission Inquiry Report, No. 33, 28 February 2005, Commonwealth of Australia, Canberra.

Sheppard, J., (1995). A resource dependence approach to organisational failure. Social Science Research, 24, pp.28-62.

Stretch, T., Carter, C., and Kingwell, R., (2014), The cost of Australia's bulk grain export supply chains, [online]

http://www.aegic.org.au/media/22950/140130\%20Final\%20AEGIC\%20Supply\%20Chains\% 20Report.pdf [Accessed December 21 2015]. 
Sydney Morning Herald, (2015), GrainCorp shares soar on new PM, prompting fresh takeover speculation, [online] http://www.smh.com.au/business/markets/graincorp-sharessoar-on-new-pm-prompting-fresh-takeover-speculation-20150916-gjo7lv.html [Accessed December 16 2015].

Sydney Morning Herald, (2012), Glencore agrees to deal for Canada's Viterra, [online] http://www.smh.com.au/business/world-business/glencore-agrees-deal-for-canadas-viterra20120320-1vigo.html [Accessed March 17 2016].

Sydney Morning Herald, (2011), Nationals call for block on AWB takeover by Cargill, [online] http://www.smh.com.au/business/nationals-call-for-block-on-awb-takeover-bycargill-20110429-1e09b.html [Accessed December 16 2015].

Whitwell, G., and Sydenham, D., (1991), A Shared Harvest - The Australian wheat industry 1939-1989, Macmillan Education Australia, Melbourne.

Williams, J., (2012), Grain price volatility - a problem, a necessity, and cause for reform, Paper selected for presentation and the IFAMA 22nd Annual World Symposium, 'The Road to 2050: The China Factor', Shanghai, China, June 11-12 2002, [online] http://www.ifama.org/files/conf/2012/716.pdf [Accessed December 17, 2015].

Wry, T., Cobb, J., and Aldrich, H., (2013), More than a metaphor: Assessing the historical legacy of resource dependence and its contemporary promise as a theory of environmental complexity, The Academy of Management Annals, 7(1), pp.441-488. 